\title{
Complex treatment of recurrent pulmonary vein stenosis
}

\author{
Yaroslav Mykychak
}

\author{
Ukrainian Children’s Cardiac Center (Kyiv)
}

\begin{abstract}
Pulmonary vein stenosis (PVS) in children is a rare heart disease characterized by high recurrence and mortality rates. Objective. We describe a case of recurrent PVS, which was treated surgically and subsequently with repeated balloon angioplasties.

Materials and methods. Echocardiogram showed total anomalous pulmonary venous connection, mixed form. A CT scan of the chest confirmed the diagnosis. Month later after initial surgery angiography detected the presence of stenosis in all pulmonary veins.

Results. Currently patient has moderate residual stenosis in each PV. His prognosis is considered bleak due to continuous requirement in aggressive interventions in order at least temporarily resolve pulmonary vein stenosis.

Conclusions. Pulmonary vein stenosis still bears high recurrence, reintervention and mortality rates. Rigorous surveillance and combination of surgical and interventional treatment is warranted in this subset of patients to maintain quality of life.
\end{abstract}

Key words: pulmonary vein stenosis, pulmonary hypertension, totally anomalous pulmonary venous connections.

Pulmonary vein stenosis (PVS) in children is an extremely rare heart disease characterized by high recurrence and mortality rates.

There are two different forms of PVS in children: primary congenital PVS, which is isolated or associated with other congenital heart diseases, and acquired or secondary PVS, which occurs most commonly after repair of total anomalous pulmonary venous connection (TAPVC). PVS associated with TAPVC could be further divided: there may be PVS primarily associated with TAPVC and PVS which develops after TAPVC repair. Primary congenital PVS has a much worse prognosis than acquired.

More than sixty years have passed since the first reports about PVS have been published [1]. PVS treatment methods include endovenectomy, left atrial tissues plasty, patch plasty, balloon angioplasty, pulmonectomy and heart-lung transplantation, sutureless repair (marsupialization - atriopericardial anastomosis) and medical therapy. New pharmacologic agents that may prevent the progression of the disease are currently under investigation.

Unfortunately, the outcomes are still unsatisfactory, "and the search for an effective treatment remains a source of frustration" [2].

We describe a case of recurrent PVS, which was treated surgically and subsequently with repeated balloon angioplasties.

Case report. A two-day-old boy weighing $3.3 \mathrm{~kg}$ was referred to our clinic with cyanosis, respiratory distress, and hypoxia. Echocardiogram (echo) showed total anomalous pulmonary venous connection, mixed form: the pulmonary venous confluence
(PVC) received venous drainage from right upper (RUPV), right lower (RLPV) and left lower (LLPV) pulmonary veins. The PVC drained into the coronary sinus.

Left upper pulmonary vein (LUPV) drained via vertical vein into the innominate vein. Ostium secundum atrial septal defect(ASD) wasalso found. ACT scan of the chest confirmed

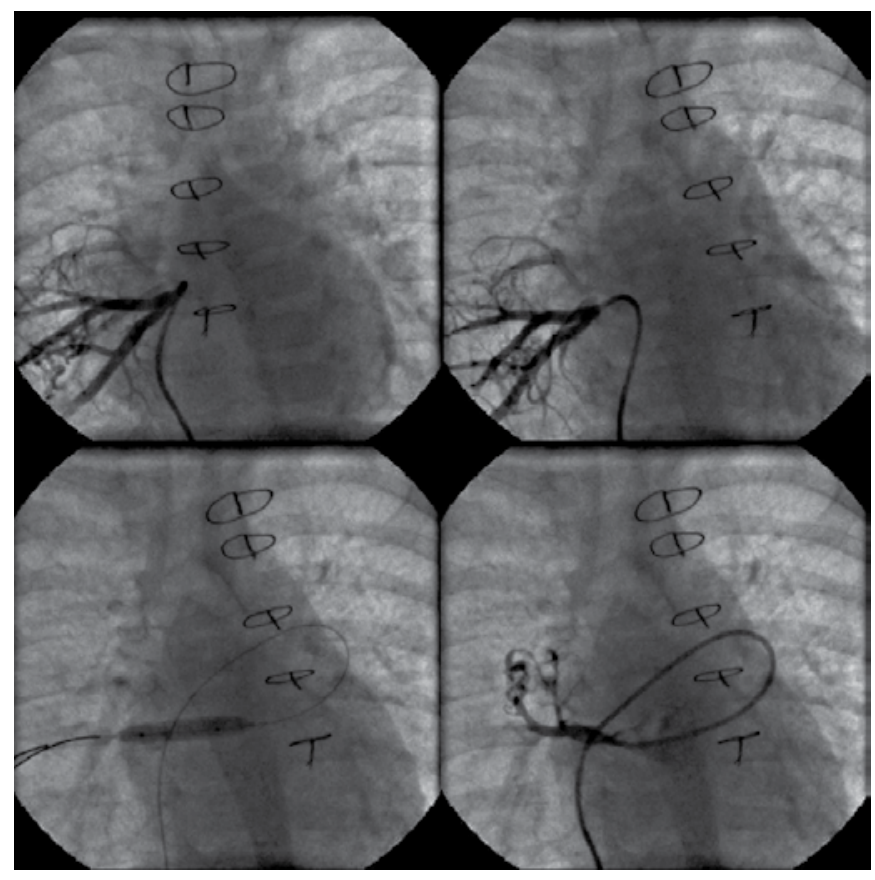

Fig. 1. Selective pulmonary vein angiography and RPV balloon angioplasty 
the diagnosis and identified unobstructed pulmonary veins. TAPVC repair was performed using aorto-bicaval cannulation for cardiopulmonary bypass, antegrade cardioplegia and moderate hypothermia. After ligation and division of the PVC and vertical vein, direct anastomosis was created between PVC and the left atrium (LA), and between vertical vein and left atrial appendage.

One month after TAPVC repair the chest CT scan demonstrated mild ostial narrowing of left upper, right upper and right lower pulmonary veins. One month later echocardiography demonstrated severe PVS and pulmonary hypertension. Angiography confirmed the presence of stenosis in all pulmonary veins, with occlusion of upper right and left PVs and mean pressure gradients of 8 and $15 \mathrm{~mm}$ $\mathrm{Hg}$ over lower left and right PVs, respectively. These findings warranted a surgical repair: a complex autopericardial patch angioplasty of all four pulmonary veins was performed and ASD fenestration was left to facilitate further interventions.

Four months following the TAPVC repair and one month after the initial PVS repair angiography revealed severe hypoplasia/occlusion of RUPV, which drained via collaterals into the right middle pulmonary vein (RPV); severe right PVs stenosis, moderate LLPV stenosis. LUPV had a narrowing $12 \mathrm{~mm}$ distally from the left atrium. The patient underwent balloon dilatation of the RPV (figure 1). RPV mean pressure gradient reduced from $35 \mathrm{mmHg}$ to $22 \mathrm{mmHg}$. Also, LLPV angioplasty was performed. LLPV mean pressure gradient reduced from $25 \mathrm{mmHg}$ to $20 \mathrm{~mm} \mathrm{Hg}$.

Afterwards, during the next eight months a series of four angiographies was performed, during which patient required repeated RPV, LLPV balloon angioplasties, RUPV recanalization, and artificial ASD dilatation.

Eighteen months after TAPVC repair echo revealed severe pulmonary vein stenosis: maximum right pulmonary veins pressure gradient was $19 \mathrm{mmHg}$, mean $12 \mathrm{mmHg}$. Maximum left pulmonary veins pressure gradient was 29 $\mathrm{mmHg}$, mean $13 \mathrm{mmHg}$.

Surgical PVS repair was performed. During surgery right PVs occlusion was identified and repaired with autopericardial patch. Further revision revealed a significant endothelial hyperplasia of the vertical vein-left atrial appendage anastomosis. Endothelium was excised, anastomosis was expanded with autopericardial patch. Atrial septum was reconstructed with $0.3 \mathrm{~mm}$ PTFE patch with $4 \mathrm{~mm}$ fenestration.

Follow-up angiography indicated an unobstructed outflow from left pulmonary veins and RPVs ostial narrowing. Both veins were dilated with balloons.

23 months after TAPVC repair angiography found next findings: intact interatrial septum, right PVs, LLPV ostial narrowing. Artificial ASD was reopened and dilated. Pulmonary veins balloon angioplasty was performed.
Discussion. After the initial TAPVC repair this patient underwent a total of two surgical PVS repair, 7 balloon angioplasties, 10 angiographies and 2 CT scans. Now he is free from pulmonary hypertension and has moderate residual stenosis in each PV. Patients prognosis is considered bleak due to continuous requirement in aggressive interventions in order at least temporarily resolve pulmonary vein stenosis.

The optimal management of pulmonary vein stenosis in children remains undetermined. The sutureless technique may be an effective technique even for the primary repair of TAPVC [3]. Kalfa and colleagues [4] presented an analysis of multi-institutional experience of 14 European and North American institutions with postsurgical pulmonary vein stenosis (PSPVS). They demonstrated that residual severity of the disease is the main prognostic factor for adverse outcomes regardless of the repair method. Sutureless repair was protective against recurrence. Also authors demonstrate that severity of residual stenosis is an independent risk factor for poor long-term outcomes. Quinonez and co-authors [5] report that even with the sutureless repair approximately $30 \%$ of patients with PVS will undergo reoperation or die within 2 years and will require aggressive reinterventions. Vanderlaan and colleagues [6] offer early detection of recurrent disease as a rational approach to improving outcomes.

Conclusion. Pulmonary vein stenosis still bears high recurrence, reintervention and mortality rates. Rigorous surveillance and combination of surgical and interventional treatment is warranted in this subset of patients to maintain quality of life.

\section{Reference}

1. REYE RDK. Congenital stenosis of the pulmonary veins in their extrapulmonary course. Med. J. Aust. 1951; 1(22):801-802.

2. Lacour-Gayet F, Lopez L, Davidson J, da Cruz EM. Pulmonary Vein Stenosis. In Da Cruz EM, Ivy D, Jaggers J (eds): Pediatr. Congenit. Cardiol. Card. Surg. Intensive Care, London: Springer London, 2014:1905-1918.

3. Mueller C, Dave H, Pretre R. Primary correction of total anomalous pulmonary venous return with a modified sutureless technique. Eur J Cardiothorac Surg 2012;43:63540.

4. Kalfa DK, Belli E, Bacha E, Lambert V, di Carlo D, Kostolny M, et al. Outcomes and prognostic factors for postsurgical pulmonary vein stenosis in the current era. $\mathbf{J}$ Thorac Cardiovasc Surg. 2018;156:276-86.

5. Quinonez LG, Gauvreau K, Borisuk M, Ireland C, Marshall AM, Mayer JE, et al. Outcomes of surgery for young children with multivessel pulmonary vein stenosis. J Thorac Cardiovasc Surg. 2015;150:911-7.

6. Rachel D. Vanderlaan and Christopher A. Sutureless repair and postoperative residual stenosis: "Never leave with a lesion”. J Thorac Cardiovasc Surg 2018;156:287-8. 


\section{Комплексне лікування рецидивуючого стенозу легеневих вен}

\section{Микичак Я. Б.}

ДУ «Науково-практичний медичний центр дитячої кардіології та кардіохірургії М03 України» (Київ)

Стеноз легеневих вен (СЛВ) - рідкісне серцево-судинне захворювання, що характеризується тяжким перебігом і високим рівнем рецидивування та смертності.

Класифікація СЛВ досить неоднозначна, що зумовлено досить частим поєднанням з іншим вадами, складними механізмами розвитку.

У дітей виділяють первинний вроджений (ізольований або поєднаний з іншими вадами) та набутий після хірургічного лікування вроджених вад серця, найчастіше - тотального аномального дренажу легеневих вен (ТАДЛВ). При цьому СЛВ, пов'язаний із ТАДЛВ, посідає особливе місце: він може бути як первинно поєднаним, так і виникати після хірургічної корекції цієї вродженої вади серця. Вроджений СЛВ має значно гірший прогноз, ніж набутий. Для лікування застосовують ендовенектомію, пластику тканинами лівого передсердя, аутоперикардом та іншими матеріалами, балонну ангіопластику, пульмонектомію та пересадку серця-легень, «безшовну корекцію» (марсупіалізація - атріоперикардіальний анастомоз) та цитостатичну терапію. Нещодавно розпочато дослідження лосартану як засобу, що може пригнічувати прогресування захворювання. На жаль, результати досі незадовільні, а «пошук ефективного лікування залишається джерелом розчарування» [2].

Мета роботи. В цій роботі представлено випадок лікування пацієнта з рецидивуючим вираженим стенозом легеневих вен за допомогою повторних хірургічних втручань та балонних ангіопластик.

Матеріали та методи. Під час ехокардіографічного дослідження було виявлено тотальний аномальний дренаж легеневих вен (ТАДЛВ), змішана форма. За допомогою комп'ютерної томографії (КТ) діагноз підтверджено. Проведено хірургічну корекцію ТАДЛВ. Через місяць після хірургічного втручання під час проведення агіографічного дослідження було встановлено стеноз усіх легеневих вен.

Результати. Загалом пацієнту було проведено 7 балонних ангіопластик. В даний час у пацієнта зберігається помірний залишковий стеноз в усіх легеневих венах. Через постійну необхідність в агресивних інтервенціях прогноз залишається несприятливим.

Висновки. Стеноз легеневих вен все ще супроводжується високим рівнем рецидивів, реінтервенцій та летальності. Ретельне спостереження та комбінація хірургічного та інтервенційного лікування необхідні в цій групі пацієнтів для підтримання якості життя.

Ключові слова: стеноз легеневих вен, легенева гіпертензія, тотальний аномальний дренаж легеневих вен. 